\title{
Major Trends of Russia's Tax Policy in Strategy of National Economic and Political Security
}

\author{
(case study of oil producing industry)
}

\author{
E. N. Gorbunova \\ Yugra State University \\ Khanty-Mansiysk, Russia \\ E-mail: gorbunovaen@mail.ru
}

\begin{abstract}
State tax policy as one of the most important regulatory tools of the state economy determines major trends of a country's development. Tax policy is aimed at addressing economic and political challenges that a state faces. Issues of the national economic and political security assurance are caused by many factors, for instance, the sanctions imposed against Russia over the last years, as well as relatively low oil prices. The challenges, surfacing in the oil industry due to the Russian tax legislation constantly being changed, have been up for special debate, both on the part of the state and the leadership of oil companies. The inefficient state tax policy and faulty public administration intensify threats to the national economic and political security leading to recessional trends in the taxation system. These circumstances result in decline in both budget revenues and state financial support. In this research, the main problems that arise while implementing major trends of the state tax policy in the oil industry have been studied. The purpose of the study is to develop a specific tax mechanism for taxing oil companies. A number of research papers, journal articles and other publications, including the Internet, were used for this study to be a basis for researching the issues of the paper topic. When studying the major trends of the state tax policy in the oil industry, methods of qualitative and comparative material analysis were employed, as well as statistical data. Results of the study show that switching to oil corporate taxation is one of the major trends of the state tax policy in the oil industry. The author concludes about the need to incorporate the added income tax into the Russian tax and fee system.
\end{abstract}

Keywords - tax policy, economic security, political security, oil producing industry, tax mechanism, oil industry taxation

\section{INTRODUCTION}

Modern development of Russia is characterized by increased attention to the process of establishing an effective tax system that ensures withdrawing excess profits generated in the oil extraction in favor of the state.

According to the Russian Ministry of Finance, petroleum revenues to the budget in 2017 amounted to 8.208 trillion RUB. With that said, the share of petroleum revenues in the overall structure of federal budget revenues would be decreasing from $51 \%$ in 2015 to $50.8 \%$ in 2016 , and to $49.6 \%$ in 2017 [1].
As per the "Major Trends of Tax Policy in 2017 and for the 2018-2019 Planning Period" Project (hereinafter referred to as Major Trends of Tax Policy), further taxation system improvement is expected in 2018-2019. In order to stimulate development of new oilfields and rational subsoil use, a new taxation system is expected to be introduced for pilot facilities, including both green and mature oilfields. The new system provides for reducing the total amount of taxes dependent on gross figures (mineral extraction tax for oil and oil customs duty) and imposing the added extraction income taxation (hereinafter - AIT). As the result, higher flexibility of taxation is ensured due to the tax amount dependent on economic performance obtained from economic result of the oilfield development.

In accordance with the Major Trends of Tax Policy, the tax policy of the Russian Federation shall meet modern global challenges, among which, first of all, the sanctions imposed against Russia and low oil prices. In the medium and long term, the Russian Government's priority on tax policy is to further enhance the tax system efficiency.

The main objectives of the tax policy are, on the one hand, maintaining budget sustainability, obtaining the required amount of budget revenues, and, on the other hand, supporting entrepreneurial and investment activities that ensure state tax competitiveness on the world stage.

Recently, the Russian Government has brought up raising oil industry taxes and withdrawing additional revenues generated from the ruble depreciation. The Russian Ministry of Finance proposed to channel oil money to offset the budget deficit.

The present study has examined possible options for further reforming the oil industry taxation and made conclusions about the need to establish a rent-oriented tax system.

The main goal of reforming the oil taxation is to develop and implement a modern and efficient tax regime that would ensure continuous and stable flow of tax budget revenues and contribute to the long-term oil industry development.

The reform implemented in recent years has made it possible to significantly improve budgetary efficiency of the 
tax system and bring it closer to international practices. In contrast, the changes made have failed to address all of the issues. Deteriorating oil production conditions require further tax system improvement, providing necessary incentives for investments in the new oilfields development.

Over a long period of time, Russian oil tax legislation was aimed at ensuring an adequate level of tax budget revenues at all costs. Economic efficiency, in this case, assumed to be less important. This resulted in an extremely unfavorable tax climate hampering intensive development of the industry and its efficiency improvement.

\section{LITERATURE REVIEW}

According to experts, the existing taxation system hampers investments in new oilfields development, failing to stimulate keeping the production volume in depleted areas up. The system is still focused on mature deposits. To make new oilfields attractive for oil industry companies, it is necessary to significantly reform the legislation [2].

Due to lower oil prices and the decline in investments volume by oil companies, the increase in oil and gas costs over planned periods while developing hard-to-recover oilfields and the Arctic shelf is called into question. To reduce losses from adverse consequences under current macroeconomic conditions, a bill to impose the added extraction income tax in the oil industry was introduced in the State Duma of the Russian Federation in 2017 [3].

However, in the view of the Russian Ministry of Finance, imposing the AIT in the oil industry will result in selective introduction of preferential taxation for randomly selected investment projects. What is more, the feature of the AIT draft bill is that tax options imply accelerated depreciation and, as a consequence, the state's refund of oil production capital costs, however, this will negatively affect the investments efficiency. Also, the Russian Ministry of Finance is wary of the fact that if the mineral extraction tax (hereinafter - MET) was abolished and the AIT was introduced, the federal budget would lose stable revenues from the previous tax with a more specific tax base [4].

Recently, there has been quite intense discussions that the oil industry tax system needs to be reformed by introducing the added income tax in Russia. The AIT is a tax imposed on the difference between the oil sold and its extraction cost. Thus, the AIT is a taxation of additional (net) income arising from natural resources extraction. The use of the AIT stimulates investment in developing new oilfields, since the tax may not be charged until the full recovery of capital costs. When oilfields are being developed, the AIT is usually lower than the MET due to significant costs, however, as the project progresses, the growing AIT compensates for budget tax losses occurring at the start of the field development [5].

The idea to introduce the AIT as an experiment is actively supported by oil industry representatives. Vagit Alekperov, President of OAO "LUKOIL", explains that oil extraction from operating fields is at the final stage, with no new prepared oilfields available; it is necessary to boost geological exploration to develop new oilfields, including small and medium-sized ones; introducing the AIT will provide for creating and launching new assets for further development and oil production [6].

Yet, OAO "LUKOIL" Vice-president Leonid Fedun was sure that "life would make" the government introduce the AIT, when oil production started falling in Russia in 2015-2016. Having said this, he stressed that "the world oil taxation system is like a seesaw: at the initial development stage taxes are low; as soon as the field reaches its peak, so do taxes; production begins falling, then taxes reduce again [7].

Thus, there is an obvious conflict of interest between Russia's Ministry of Energy and Ministry of Finance when it comes to introducing the AIT. In this context, it is important to find necessary balance between regulatory and fiscal functions of this tax, since "the main goal of the tax reform is to develop and implement a modern and efficient tax regime that would ensure a continuous and stable flow of tax revenues to the budget, and contribute to the long-term development of the oil industry" [8].

In their works, G.R. Golovanov, M.A. Ilyichev, E.N.Komissarova, V.S. Pancheva, E.A. Sutkevich, S.V. Chernyakovskiy, and other researchers addressed challenges the government faces implementing anti-crisis measures and studied the Russian oil industry taxation itself as an economic recovery measure. ${ }^{1}$

In addition, the "Energy Strategy of Russia 2035"2, being drafted by the Russian Ministry of Energy and announced on September 20, 2017 at the 7th Oil and Gas Forum in Tyumen, states that introduction of the AIT on production is a key element of the "new tax system" and is of high priority for the energy industry development. As planned by legislators, this will ensure flexibility and target orientation of taxation due to dependence of the tax level on economic result of the oil well development.

\section{RESEARCH MATERIALS AND METHODS}

The methodological framework of the study is based on fundamental economic concepts in the field of taxation theory; the works of international and domestic scientists on tax policy issues analysis, as well as experts' publications on specific issues of Russia's modern tax policy. The research methods employ principles of historical, expert, statistical, logical and comparative analysis, as well as a system approach to study the foregoing topic. By way of comparison and analysis, the major trends of the state tax policy in the oil industry have been disclosed.

\footnotetext{
1 See G. R. Golovanov. Legal regulation of the mineral extraction tax: Thesis abstract, PhD, Law. Moscow, 2009. M.A. Ilyicheva. Legal regulation of tax relations with participation of the larges taxpayers (case study of the oil and gas enterprises): Thesis abstract, PhD, Law. Moscow, 2017. E. N. Komissarova. Legal and financial aspects of the tax policy implementation in the Russian E. N. Komissarova. Legal and financial aspects of the tax policy implementation in the Russia oil industry: Thesis abstract, PhD, Law. Tyumen, 2009. V. S. Pancheva. Improving the taxatio of oil and gas production in Russia: Thesis abstract, PhD, Economics / V. S. Pancheva. Moscow, 2015. E. A. Sutkevich Legal regulation of subsoil use fees in the Russian Federation Thesis abstract, PhD, Law. Moscow, 2013. S. V. Chernyakovsky. The concept of reforming the withdrawal of differential mining rent in the Russian oil industry: Thesis abstract, Doctor, Law S. V. Chernyakovskiy. - Moscow, 2013

2 The project is posted on the Russian Ministry of Energy official website. Access mode: https://minenergo.gov.ru/node/1920 (access date 01.02.2018).
} 
The information framework of the study are the law and regulations of the Russian Federation, related to the topic in question; scientific, methodological, educational publications of domestic and international scientists; information, analytical, reference sources; statistical data reported in official editions; the proceedings of scientific conferences. The practical part includes statistical reporting data of the Russian Ministry of Finance.

The President of the Russian Federation Vladimir Putin suggested "within the next year to thoroughly and comprehensively consider proposals to adjust the taxation system, be sure to do this with the participation of business associations. Despite the internal political calendar, it is still necessary for us in 2018 to prepare and adopt all the relevant amendments to the legislation, to the Tax Code, and from January 1, 2019 to put them into effect, fixing new stable rules for a long-term period. At the same time, I request the Government to address the issues of mechanisms improvement for ensuring a stable budget and public finances, fulfilling all of our obligations, regardless of external factors, including hydrocarbon prices "[9]. In order to stimulate the development of new deposits and the rational subsoil use, a new taxation system (AIT) is envisaged for pilot facilities, including both new and mature deposits. The new system provides for a reduction in the total amount of taxes that depend on gross indicators (MET and oil customs duty) and an introduction of the added extraction income taxation. As a result, higher flexibility of taxation is ensured due to the dependence of the taxes amount on the economic performance of the reserves development.

The AIT base is proposed to be defined as hydrocarbon production estimated revenues minus operational and capital oil field development costs, with the tax rate to be fixed at $50 \%$. Herewith, for organizations employing AIT, the current income tax calculation procedure remains effective, but with a reduction in the taxable base in the amount of the AIT paid .

In order to limit incentives to overstate costs and to minimize budget shortfall in revenue, the deductible costs for mature fields are limited to 9520 rubles per ton of produced hydrocarbon crude, adjusted for inflation. Depending on the implementation results of the AIT in pilot projects, a decision will be made whether to adjust and expand the application range.

Furthering a purpose to ensure a rental income tax equity during the planning period, further steps provide for the convergence of the rental income tax burden in the oil industry.

In order to reduce the deficit of the federal budget, it is proposed to increase the tax burden on the oil and gas industry within the 2017 - 2019 period by specifying the MET rate calculation procedure for oil as to complementing its calculation formula with a new 14th addendum fixed for the 2017 at a rate of 306 rubles, for 2018 - 357 rubles, for 2019 428 rubles.

It is also proposed to amend the basic value calculation formula for a unit of equivalent fuel to be employed to fix the MET rate for natural and condensate gas production. The changes are designed to increase the MET rate for natural gas production exclusively for organizations that own the Unified Gas Supply System facilities and affiliated companies. Additional revenues to the federal budget in 2017 will amount to 170 billion rubles, in 2018 - 125 billion rubles and in 2019 -130 billion rubles.

It is proposed to change the taxation mechanism for the multicomponent complex ores extraction by fixing specific MET rate in the amount of 730 rubles per ton. This mechanism will be applied to multicomponent ores extraction in the Krasnoyarsk Region.

It is planned to monitor the application of the existing taxation mechanism for oil, gas condensate, and combustible natural gas production, including new offshore fields, and feasibility analysis of the authority delegation to regional authorities to fix MET rates and to assess the tax base by types of mineral resources that belong to widespread mineral resources, and, if needed, to amend the legislation.

In parallel, other amendments to the tax legislation within the hydrocarbon production taxation have come into effect, which affected the MET calculation mechanism. In particular, the calculation procedure for the degree of oil production complexity, alongside the MET final rate calculation have been modified; how regional specific features of the oil field location and its properties influence on the MET rate have been considered; applicability of a zero oil tax rate has been changed. Of note, there is a MET differentiation due to increase in a number of factors that determine the mining specific feature of the minerals extraction [10].

Due to the high competition on world hydrocarbon markets, maintaining of production and putting new oil fields into production are becoming extremely important for the Russian oil industry. The oil industry needs tax incentives in order to be competitive on world markets.

It is evident that at present time our country, with its unstable market economy, should stay reasonable and employ two taxes for the oil production: MET and AIT, which are meant to withdraw various types of rent (absolute and differentiated) stemming from subsoil use.

Additionally, further work on the draft law on excess profits tax for oil companies should be done. After the excess profit tax for oil companies has been enacted, it is possible to cancel the MET.

Thus, there is an obvious conflict of interest between the Ministry of Energy of the Russian Federation and the Ministry of Finance of the Russian Federation in terms of AIT introduction. In this context, it is important to find the necessary balance between regulatory and fiscal functions of this tax, since "the main goal of a tax reform is to develop and implement a modern and efficient tax regime that would ensure a continuous and stable flow of tax revenues to the budget and contribute to the long-term development of the oil industry."

Such balance has not been stricken yet: rather than levying the AIT, the MET is being reformed, with a number of 
privileges granted causing huge losses to the budget of the Russian Federation.

\section{RESULTS AND DISCUSSION}

One of the possible ways to change the taxation on oil companies involves significant reduction of the MET and export duties and replacing them with the new additional income tax (AIT).

Its imposition is meant not to tax oil at the time of extraction, as it is now, but taxing the profit accumulated during the oil production in the sense of difference between income and costs over the whole period of site development.

The tax base of the AIT is defined to be the cost of produced and sold hydrocarbons, reduced by the cost of production and sales of products (less depreciation), alongside production capital investments and non-reimbursed costs over the previous tax period.

The AIT is assumed to have applied to four groups of oil fields: new oilfields in Eastern Siberia, which production output is less than 5\%; oilfields with export duty exemption; West Siberian oilfields depleted from $10 \%$ to $80 \%$, and new oilfields in the foregoing region, which production output is less than 5\%, with the total annual reserves not more than 50 million tons.

The tax rate will amount to $50 \%$, it will be imposed on oil revenues less the export duty, reduced MET, extraction and transportation costs.

Unlike the MET, the AIT is based on additional income indicators that reflect real economic efficiency of a particular oilfield development. In the case of highly efficient projects, the AIT imposition ensures progressive withdrawal of resource rent in favor of the state, with concurrent improving implementation conditions for low-efficiency projects.

The use of the AIT stimulates investments in new oilfields development, as the tax may not be charged until the full recovery of capital costs and the subsequent taxation corresponds to profitability rates. With this approach, it is not only producer's gross income that is reckoned, but also oil production costs at a particular field. The tax system designed in such a way does not put economic barriers to the oilfields development being characterized by increased capital, operational, transportation costs.

Moreover, the AIT imposition is seen to be effective, mainly in new oil and gas fields. The basic difference between taxes on additional income and on financial result from the current tax system is that they focus on oil and gas production profitability, i.e., on oil company's financial performance. With such a system, economists believe natural and climatic conditions of the oil production will be objectively taken into account. In the aftermath of the AIT imposition in highmargin production, petroleum revenues to the budget will increase, while with a low-margin production, the tax burden on oil producers will decrease, which, in aggregate, will boost oil production in the country [11].
Proposals for the AIT imposition are timely and in line with international trends. With proper tax administration, the AIT will provide an impetus to develop low-margin offshore fields [12].

Thus, this is a more flexible system that shifts the burden in time, and transfers its peak value to a period of intensive development. The AIT is successfully applied in a number of tax systems of developed oil-producing countries, in particular in Norway, the United Kingdom and the United States.

With that said, under Russian conditions, the imposition of the AIT encounters the following difficulties:

Firstly, given that the tax amount will be tied in with the costs, it might be only possible to impose the AIT for relatively new fields, since it is not really feasible to document the costs of subsoil block having been developed since the Soviet era.

Secondly, the new tax will be more difficult from a tax administration perspective, since there are organizational issues with accounting and auditing oil production revenues and costs for each license block.

Finally, it may be possible to impose the AIT only after new transfer pricing control rules are adopted.

In conclusion, it should be noted that the foregoing features of establishing a specific taxation mechanism in the oil industry can and shall be extended to all extractive industries, taking into account their organizational and technological characteristics. To do so, it is the general part of the Russian Tax Code where specific features of extractive industries and their tax policy principles, aimed at subsoil rationalization, need to be declared and enshrined.

\section{CONCLUSIONS}

The attempt to introduce a new tax is explained by the need to consider oil production costs when taxing oil companies. Thus, the MET and export duty calculation depends on the oil price, while the hydrocarbon production costs are not considered. Nevertheless, the relocation of extraction fields to new territories, the complication of new development and the depletion of existing deposits lead to the need for additional privileges, because under the current taxation system the development of reserves in such zones is considered unprofitable.

However, according to the Ministry of Finance of the Russian Federation, the introduction of a profit-based tax (PBT) in the oil industry will result in selective introduction of a preferential taxation for randomly selected investment projects. What is more, the feature of the drafted PBT bill is that the tax parameters imply accelerated depreciation and, as a consequence, the state's refund of oil production capital costs, though this will negatively affect the investments efficiency. Also, concerns of the Russian Ministry of Finance relate to the fact that if the MET was abolished and the PBT was introduced, the federal budget would lose stable revenues from the previous tax with a more specific tax base [13]. 
In conclusion, I would like to highlight a number of key problems that the oil industry faces when employing the oil production taxation legislation in Russia:

Firstly, issues when applying tax exemptions for oil production taxation. Anyhow, it becomes obvious that there is a need to provide tax deductions for MET, the purpose of which will be to raise a geological exploration fund. This approach seems to be the most effective one to address the growth stimulation issue of new oil reserves, to maintain the annual rate of hydrocarbon production, and, in the long run, tax revenues and other mandatory payments to budgets from additional extraction.

Secondly, tax incentives issues for geological exploration. The solution to this problem can be accomplished by introducing surcharge rates for corporate income tax expenses. A tax deduction in the amount of expenses for effective geological exploration work from the amount of the calculated MET within MET may reserve as an alternative mechanism [14].

Thirdly, the transition to the financial result taxation. This approach allows to transfer the tax burden for the period when the project begins to actually generate revenue.

Fourthly, the transition to a different oil production taxation in Russia. The main problem is the taxation itself, where taxes (MET and export duty) are calculated based on the volume of oil produced. With this approach, the state has the same amount per ton of oil, regardless of the production cost. A similar system works perfectly when the production cost of all the reserves is approximately the same. However, in Russia this cost varies considerably not only between different oil fields, but also within particular ones.

In order to ensure that the taxation system of the Russian Federation meets modern requirements and reality of the domestic oil industry, a reform of the taxation system introducing AIT was proposed. Its key advantage is that it provides for reducing the tax burden of new undiscovered deposits with a high potential for further oil production [15]

Summarizing the aforesaid, we can draw the following general conclusions on improving the taxation system in the oil industry.

firstly, there is a need for the AIT imposition as of 2019 for some new fields;

secondly, it is necessary to maintain the tax maneuver for the period of 2019-2022;

thirdly, there is a need for having the AIT applied to all new fields in 2022 .

\section{References}

[1] N.Y. Golovetskiy, S.Y. Evdokimov, V.V. Grebenik, "Taxation Reform Mechanisms in Russian Oil Industry", NAUKOVEDENIYE Online Journal, vol. 5, pp. 18-22, 2016.

[2] Z.R. Gafarova, M.V. Gerasimova, I.A. Solovieva, "Oil and gas enterprises taxation peculiarities", Eurasian Law Journal, vol. 2, p. 218,2016
[3] M.V. Kashirina, "Relevant issues of oil industry taxation in Russia", Innovations and investment, vol. 4, p. 77, 2015.

[4] I.Trunin, Financial performance tax: privileges instead of development impetuses [Electronic source]// URL: http://minfin.ru/ ru/press-

center/?id_4=33117\&amp;area_id=4\&amp;page_id=2119\&amp;pop up=Y\#ixzz3t6LD2dfA

[5] E.G. Kostikova, "Added income tax in Russia: reform prospects for extractive industry taxation", Financial law, vol. 12, pp. 25-30, 2013.

[6] See Vagit Alekperov's interview by Vedomosti newspaper, Vedomosti. 05.09.2013. URL: http://www.lukoil.ru/ press.asp?id=4302.

[7] See Leonid Fedun's interview by BFM.RU. 24.06.2013. URL: http://www.lukoil.ru/ press.asp?id=4171.

[8] E.N. Komissarova, "Legal and financial aspects of the tax policy implementation in the Russian oil industry: Thesis abstract", $\mathrm{PhD}$ (Law). Tyumen, 2009, p. 8

[9] The Address of the President of the Russian Federation to the Federal Assembly of the Russian Federation of December 1, 2016. Access mode: http:// kremlin.ru/events/president/news/53379

[10] The Federal Law of the Russian Federation dated November 24 , 2014, No. 366-FZ "On Amendments to Part Two of the Tax Code of the Russian Federation and Certain Legislative Acts of the Russian Federation", Collection of the legislation of the Russian Federation, December 1, 2014 No. 48. Art. 6647

[11] E.N. Gorbunova, "Tax Policy in the Oil Industry of Russia: From tax maneuvers to industry's taxation reform", Taxes and Finance, vol. 1, p. 38, 2016.

[12] P.O. Uvarov, A.A. Adaeva, Z.A. Aliaskhabov, "Consequences following the introduction of the added income tax as a component of the tax reform of the oil industry, case study of the South Kirinsky oil field", Economic Systems Management: electronic scientific journal, vol. 5, pp. 31-36, 2017.

[13] On implementation of the "tax maneuver" in the oil industry, June 20 2015, The official website of the Government of the Russian Federation, URL: http://government.ru/info/19405.

[14] I. Trunin Tax on financial result: privileges instead of incentives to development. Available at: http://minfin.ru/ ru/presscenter/?id_4=33117\&amp;area_id=4\&amp;page_id=2119\&amp;pop up=Y\#ixzz3t6LD2dfA

[15] L.P. Pavlova, T.A. Bloshenko, V.V. Ponkratov, M.M. Jumaev, The theory and practice of formation and administration of tax base in branches of a mineral and raw complex: monograph, Moscow: Financial University, 2014, p. 132 